\title{
Influence of Size Effects on the Properties of Processed Iron Ore and Schungite Rock
}

\author{
Yu. Mirgorod ${ }^{1}$, S. Emelianov ${ }^{1}$, V. Fedosjuk ${ }^{2}$, S. Bolshanina ${ }^{3, *}$ \\ ${ }^{1}$ Southwest State University, 94, 50 Let Ockyabrya St., 305044 Kursk, Russia \\ ${ }^{2}$ Institute of Solid State and Semiconductor Physics, National Academy of Sciences of Belarus, SSPA Scientific and \\ Practical Center for Materials Science, 220072 Minsk, Belarus \\ ${ }^{3}$ Sumy State University, 2, Rimsky Korsakov St., 40007 Sumy, Ukraine
}

(Received 28 March 2016; published online 21 June 2016)

\begin{abstract}
Scanning electron microscopy, energy dispersion spectroscopy, X-ray diffractometry and magnetometry methods were used to investigate the structure and magnetic properties of iron ore and schungite rock. The results show the existence of external size effect in iron ore concentrate. It is related with the penetration of iron nanoparticles from equipment surfaces onto the powder surface, which increases specific magnetic saturation of the powder by 1.6 times compared with pure magnetite. As a result of internal size effect in schungite powder its reactivity decreases by $800{ }^{\circ} \mathrm{C}$ and after heat treatment of the powder its specific magnetic saturation increases by seven times. Considering the application of size effects the investigated powders and waste natural mineral powders are recommended to be used in the production of composite materials.
\end{abstract}

Keywords: Size effect, Physical and chemical methods, Powder, Nanoparticles, Iron ore, Schungite rock, Structure, Specific magnetization.

DOI: $10.21272 /$ jnep.8(2).02053

PACS number: 75.75.Cd.

\section{INTRODUCTION}

Size effects are phenomena that are demonstrated in technologically notable changes in physical-chemical properties and reactivity depending on the number of atoms and molecules in a substance particle [1]. Size effects are usually related with nanoparticles with a size of up to $100 \mathrm{~nm}$. However these effects should not be limited to this size. For instance, melting temperature of $100 \mathrm{~nm}$ nanoparticles of silver is by $123 \mathrm{~K}$ less than that of bulk metal. Small additives of nanoparticles with extremely small sizes of 1-5 nm can result in a significant size effect of the composition built up from microparticles. Size effects can be internal and external. Internal effect is related with specific changes in bulk and surface properties of both individual particles and their ensembles resulting from self-organization process. External effect is a dependent response to an external field or force action independent from the internal effect [2].

Ore processing makes an intensive use of internal size effect - a significant change in the Gibbs energy of a surface that develops during the dispersion of minerals. A notable positive change in the thermodynamic parameter in dispersion process is a driver of the absorption of flotation reagents on the surface of minerals [3]. According to [4] when $\mathrm{MgSO}_{4}$ and $\mathrm{Na}_{2} \mathrm{SO}_{4}$ are floated by means of anionic or cation collectors the best flotation effect is observed in $\mathrm{MgSO}_{4}$ salt that disrupts water structure on the power surface. Thus, the properties determined by structural organization of anionic and cation hydration water should be characterized as the internal size effect.

In thermodynamic method the reactivity of a substance is defined by Gibbs energy. It describes the ability of a substance to transit to another phase or enter into a reaction, and shows that the system is far from its equilibrium state. An increase in the dispersion of a substance increases its reactivity [1] and results in the deviation of the system from its equilibrium state. The size of particles "plays the role" of temperature, i.e. it activates particles. So the size of particles is a thermodynamic parameter like pressure, volume or temperature of a system.

In the process of its concentration iron ore gets in touch with equipment parts made from iron alloys. It is not only ore that is crushed up. Equipment materials affected by vibration, friction and load impacts also become dispersed and can get into iron-ore concentrate. Moreover, iron-ore powder gets additionally activated as a result of the yield of metastable structures onto the surface of ore particles. Report [5] about the discovery of superparamagnetic magnetite nanoparticles with a size of 2-14 $\mathrm{nm}$ in the mineralized areas of Colorada iron-ore deposit field in the south of Mexico.

Schungite rocks (Karelia), like iron ore, are very different in their material composition. Carbonaceous substance, that is present in the ore, makes up a matrix with unevenly distributed grains of quartz and sometimes of mice, calcium or magnesium carbonates, ferric oxide, as well as such microelements as $\mathrm{Cu}, \mathrm{Zn}$, $\mathrm{Ni}$ and $\mathrm{Cr}$ [6]. It is considered that at a temperature below $1300{ }^{\circ} \mathrm{C}$ there are no any notable signs of schungite rock transformation. Schungite powder with $65 \%$ carbon content was processed into silicized carbon at a temperature of $1450{ }^{\circ} \mathrm{C}$. In contrast to ferromagnetic properties of iron ore, schungite matter has diamagnetic properties [6].

In this paper we investigate internal and external size effects that can change magnetic properties of iron ore and schungite mineral powders. There are also some recommendations regarding the use of new mate-

\footnotetext{
*svet.bolshanina@gmail.com
} 
rials with size effects as a result of reprocessing already dispersed minerals.

\section{MATERIALS AND METHODS}

\subsection{Materials}

Ore powder and "dry concentrate" (from Mikhailovsky GOK - Ore Mining and Processing Enterprise, Kursk Region, Russia) were used. Ore powder had grey color. Dry concentrate was black like magnetite. Schungite rock was from Zazhogin field (Karelia, Russia). It was milled in the laboratory without any contact with Fe. At the last stage of its processing it was grinded in an agathic mortar down to the state of black-color fine powder.

\subsection{Methods}

X-ray powder diffractometer EMMA (Enhanced Multi-Materials Analyzer) was used. Its accelerating voltage is $60 \mathrm{kV}$, current $-80 \mathrm{~mA}$ and radiation power $-2 \mathrm{~kW}$. Ceramic tube with $\mathrm{Cu}$ anode and bent graphite monochromator generates radiation on the line $\mathrm{Ka}$ with a wave length of $0.154 \mathrm{~nm}$. By means of collimators the diameter of X-ray radiation spot can vary within the range of $0.4 \div 12 \mathrm{~mm}$. Angle of reflection changes in the range of $-30-150^{\circ}$. Elevation scan rate changes discretely with a preset rate (from 0.14 to 60 degrees/min), elevation scan pitch is $\Delta 2 \theta=0.03^{\circ}$. With panoramic spectrum scanning the rate can reach $60 \% \mathrm{~min}$. The diffractometer is computer controlled.

Scanning electron microscope (SEM) with LEO 1455 VP Carl Zeiss X-ray spectrum analyzer was used to measure the size of ore powder and concentrate particles and define elemental composition of the powders. Analyzer's pencil beam (electron probe) with a diameter of $1 \mu \mathrm{m}$ scans the powder surface. When beam electrons get into the sample they knock out electrons from atomic shells and cause X-ray radiation. Each element radiates with its own specific frequency set and thereby can be identified. The concentration of elements is evaluated by radiation intensity.

Magnetic studies were conducted with the help of a universal measuring system - Cryogenic high field measurement system [7].

\section{RESULTS AND DISCUSSION}

\subsection{Structure and Magnetic Properties of Iron Ore and "Dry Concentrate" Powders}

According to SEM data the sizes of particles in both powders varies in the range of 0.5-50 $\mu \mathrm{m}$. If we assume that all particles are of cubic shape with cube edges within the said dimensions, then according to calculations specific surface of the powder will vary in the range of $1200-0.12 \mathrm{~m}^{2} / \mathrm{cm}^{3}$.

As X-ray diffraction pattern shows that ore powder was composed from $\mathrm{Fe}_{2} \mathrm{O}_{3} 13.5 \%$ and $\mathrm{SiO}_{2} 86.5 \%$. Dry concentrate contained $\mathrm{Fe}_{3} \mathrm{O}_{4} 63.7 \%, \mathrm{Fe}_{2} \mathrm{O}_{3} 3.9 \%$ and $\mathrm{SiO}_{2} 32.4 \%$. Bragg reflection angles for $\mathrm{Fe}_{2} \mathrm{O}_{3}$ correspond to rhombohedral $\alpha-\mathrm{Fe}_{2} \mathrm{O}_{3}$ (JCPDS card № 330664). Ore powder X-ray diffraction pattern showed that there were no peaks matching $\gamma$ - $\mathrm{Fe}_{2} \mathrm{O}_{3}$ (JCPDS card №39-1346) and $\mathrm{Fe}_{3} \mathrm{O}_{4}$ (JCPDS card №89-4319) with spinel cubic structure. For dry concentrate powder the peak (311) with angle 360 matched $\mathrm{Fe}_{3} \mathrm{O}_{4}$ peak (311) of the reference pattern (JCPDS card №89-4319) at the same angle, however, there were no other peaks matching the same reference pattern.

In order to determine $\mathrm{Fe}_{3} \mathrm{O}_{4}$ in ore powder, the powders were investigated for the Verwey transition. The transition metal-dielectric is observed in metal at the Verwey temperature of $120 \mathrm{~K}$ with an increase in electrical resistivity by two orders. In ore and dry concentrate powders the Verwey transition was observed at a temperature of $125 \mathrm{~K}$. Specific magnetization jump at the phase transition in the ore powder was equal to $0.08 \mathrm{~A} \cdot \mathrm{m}^{2} / \mathrm{kg}$, while in the dry concentrate it was by 120 times more and amounted $9.5 \mathrm{~A} \cdot \mathrm{m}^{2} / \mathrm{kg}$.

The studies of field dependency of the magnetization of ore powder and dry concentrate Fig. 1a, b produced very interesting results. Specific magnetization saturation of dry concentrate appeared to be equal to $150 \mathrm{~A} \cdot \mathrm{m}^{2} / \mathrm{kg}$, (Fig. 1b). It was much bigger than that of individual magnetite. Specific saturation magnetization of magnetite at a temperature close to $0 \mathrm{~K}$ is $98 \mathrm{~A} \cdot \mathrm{m}^{2} / \mathrm{kg}$, and at room temperature it is $92 \mathrm{~A} \cdot \mathrm{m}^{2} / \mathrm{kg}$ (Bushow, 2006) [8]. Specific magnetization saturation of ore powder was $7.5 \mathrm{~A} \cdot \mathrm{m}^{2} / \mathrm{kg}$. Specific magnetization saturation of dry concentrate powder was 20 times more than that of ore powder and 1.6 times more than that of magnetite. Let's try to explain this interesting phenomenon.

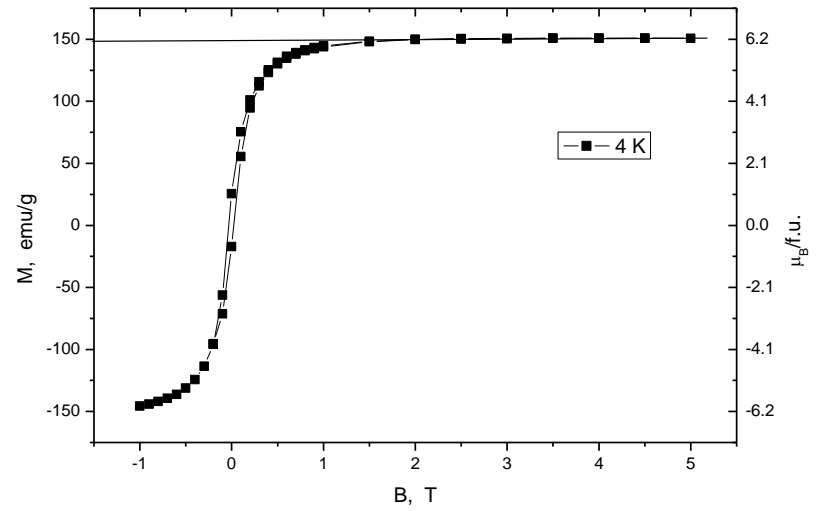

Fig. 1 - Dependency of specific magnetization on the imposed field of concentrate powder

According to the magnetization values obtained for samples it is possible to estimate mass concentration of their magnetic components:

$$
\phi_{m}=\frac{\sigma}{\sigma_{s}}
$$

where $\varphi_{m}$ is mass concentration of magnetic material (magnetite in our case), $\sigma$ is specific saturation magnetization of a sample, and $\sigma_{s}$ is specific saturation magnetization of magnetite.

The measurements of specific saturation magnetization of dry concentrate showed that, obviously, the studied samples contained a substance with a bigger specific magnetization than that of magnetite. It is possible to assume that ore and concentrate 
powders contain a small amount of pure iron that, according to research data obtained by different scholars, may vary within the range of $225-245 \mathrm{~A} \cdot \mathrm{m}^{2} / \mathrm{kg}$ [9]. In the process of ore crushing and dry or wet magnetic separation those iron parts of crushers and separators that contact with ore wear off with their fractions getting into ore or concentrate powder. Iron reference diffraction patterns (JCPDS card 87-0721) have reflections (110), (200) at angles 44.78 and 65.030. The same reflections 110) 35.10 and (200) 420 are observed in ore powder. In concentrate powder the reflection (110) 360 is notably smaller, while the reflection (200) disappears completely and is replaced by the reflection (400) that is typical of $\mathrm{Fe}_{3} \mathrm{O}_{4}$. It was found that $\mathrm{X}$-ray diffraction was not able to measure the sizes of pure iron particles and their concentration in the dry concentrate due to their extreme smallness.

Fig. 2a, b shows how the concentration of elements in powders changes in the scanning line of $112.95 \mu \mathrm{m}$.

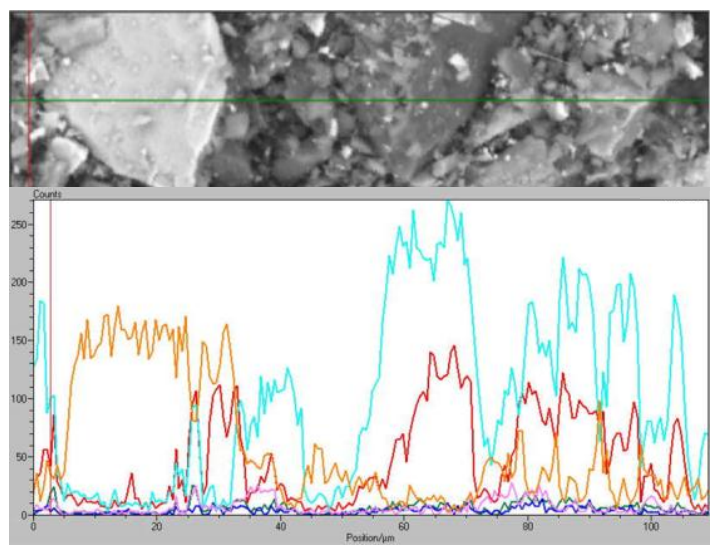

a

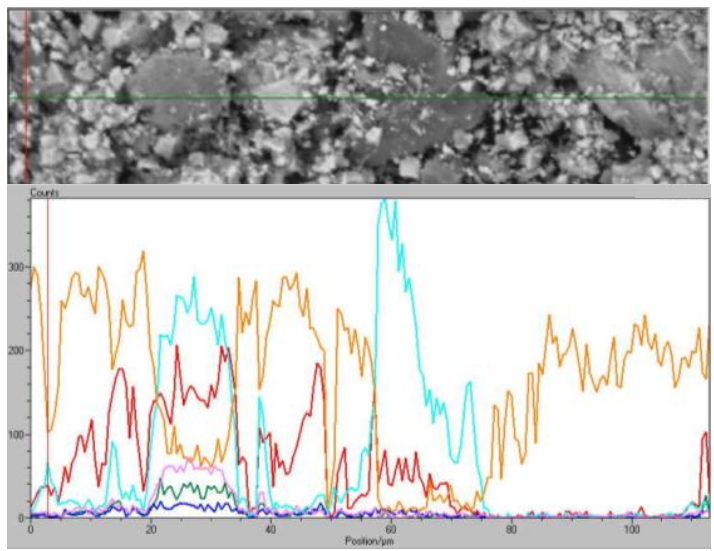

b

Fig. 2-Dependency of element concentration along powders scanning line. Brown - iron content, green - silicon content, red - oxygen content. $\mathrm{a}$ - in iron ore powder, $\mathrm{b}$ - in concentrate powder

The data was obtained with the help of LEO 1455 VP X-ray analyzer. Such elements as Fe, Si, O, Mg, Al and $\mathrm{K}$ were found in 200 points located at a distance of $0.568 \mu \mathrm{m}$ from each other. As Fig. 2 a shows, in ore powder there are six areas with predominating silicon content and only two areas with predominating iron content. On the contrary, in dry concentrate powder (Fig. 2b) there are five areas with predominating silicon content and only two areas where silicon predominates.

Tabular representation of functions (Fig. 2b) obtained by means of LEO 1455 in 200 points permitted to determine a mean ratio of iron weight concentration to the weight concentration of oxygen $\mathrm{m}(\mathrm{Fe}) / \mathrm{m}(\mathrm{O})$ in dry concentrate powder in the scanning line (Table 1) and to compare it with that in $\mathrm{Fe}_{3} \mathrm{O}_{4}$, which equaled 2.62.

Table 1 - Ore concentration of the powder with Fe, comparing with the amount of $\mathrm{Fe}$ in $\mathrm{Fe}_{3} \mathrm{O}_{4}$, along the scanning line* by the electron beam with a beam size of $1 \mu \mathrm{m}$

\begin{tabular}{|c|c|c|c|c|}
\hline № & $\begin{array}{c}\text { Scanning area, } \\
\mu \mathrm{m}\end{array}$ & $\phi_{\mathrm{Fe}_{X} \mathrm{O}_{Y}}=\frac{m(\mathrm{Fe})}{m(\mathrm{O})}$ & $\frac{\phi_{\mathrm{Fe}_{x} \mathrm{O}_{y}}}{\phi_{\mathrm{Fe}_{3} \mathrm{O}_{4}}}$ & $\begin{array}{c}\text { Reaching of } \\
\text { concentrate } \\
\text { powder with Fe } \\
\text { along the scan- } \\
\text { ning line, \% }\end{array}$ \\
\hline 1 & $0-12,49$ & 4,95 & 2,0 & 11,0 \\
\hline 2 & $34,62-44,26$ & 3,92 & 1,5 & 8,5 \\
\hline 3 & $51,08-56,19$ & 4,66 & 1,8 & 4,5 \\
\hline 4 & $70,95-77,76$ & 4,10 & 1,6 & 6,0 \\
\hline 5 & $77,76-111,24$ & 47,3 & 18,0 & 30,0 \\
\hline
\end{tabular}

*Scanning interval 0,568 $\mu \mathrm{m}$. Total 200 points.

The ratio $\mathrm{m}(\mathrm{Fe}) / \mathrm{m}(\mathrm{O})$ in pure phases of oxides equals $\mathrm{Fe}_{2} \mathrm{O}_{3}$ (2.3), $\mathrm{Fe}_{3} \mathrm{O}_{4}$ (2.6), and $\mathrm{FeO}$ (3.5). The Table shows that in all five scanning spans the desired ratio is bigger than in $\mathrm{Fe}_{3} \mathrm{O}_{4}$ and other ferric oxides. In the scanning line 77.76-111.24 $\mu \mathrm{m}$ the content of $\mathrm{Fe}$ in the concentrate powder is by 18 times more compared with $\mathrm{Fe}_{3} \mathrm{O}_{4}$. The calculated values should be even bigger considering that in that scanning line oxygen was a part of quartz as well. Such saturation of the surfaces of concentrate particles by iron nanoparticles coming from equipment parts significantly improves magnetic properties of the dry concentrate, and that is clearly demonstrated in the specific saturation magnetization experiment. There is external size effect.

Due to its outstanding magnetic properties the concentrate produced at MGOK can be used to clean water or land surfaces from oil and oil products by means of magnetic field. Moreover, it can be used to remove radioactive or toxic contaminations. According to the proposed know-how [10] the sorptive agent is mixed with oil or oil products. This composition becomes magnetized. Then it can be collected by means of magnetic devices that generate magnetic field. After that oil is separated from magnetic particles by magnetic separators, the powder is calcined and can be re-used for water cleaning operations.

\subsection{Structure and Magnetic Properties of Schungite Rock Powder}

According to SEM data the sizes of particles in schungite rock powder vary from 0.1 to $500 \mu \mathrm{m}$. The content of $\mathrm{Si}$ and $\mathrm{C}$ in the mineral changes significantly, though it dominates in comparison with other elements. Except $\mathrm{Si}$ and $\mathrm{C}$ the rock also contains oxygen and small amounts of $\mathrm{Al}, \mathrm{K}, \mathrm{Na}, \mathrm{Mg}, \mathrm{S}, \mathrm{Fe}$ and Ti. Considering that $\mathrm{K}, \mathrm{Na}$ and $\mathrm{Mg}$ are parts of carbonates, the investigated sample had very small fraction of such compounds, only about $2 \%$. Judging by the profiligram, 
like the one shown in Fig. 2, in microvolumes of up to $0.23 \mu \mathrm{m}$ the content of microelements changes significantly. It is possible to find a microvolume with $\mathrm{Si}$ $90 \%$, and the rest will be $\mathrm{Ti}$ and $\mathrm{Fe}$. There are microvolumes with $\mathrm{C} 45 \%$ or $\mathrm{Si} 45 \%$, etc. The results of elemental analysis allow us to conclude that schungite rock powder, like iron ore powder, is a microheterogeneous system consisting of phases with different elemental composition.

Fig. 3 shows diffraction patterns of the powder. The greatest intensity peak at $2 \theta=26.69^{\circ}$ (Fig. 3a) can be attributed to hexagonal graphite. After the sample was heated (Fig. 3b) the peak intensity seriously dropped from 5500 to 3500 a. u., which indicates the involvement of the graphite phase in the reduction of element compounds, for example, ferric oxides. This conclusion is verified by the appearance of micro-areas containing pure iron in schungite rock [11] Fig. 3a, b shows that after heating the powder and its subsequent cooling, reflections of all phases are shifting towards small angles. It allows us to conclude that elemental crystalline cells in the powder get bigger reaching the size of elemental cells of the corresponding phases in individual state. The intensity of reflections in the after heatingcooling diffraction pattern decreases, and that indicates the development of "dry" redox reactions at $510{ }^{\circ} \mathrm{C}$, which are accompanied by the release of gas with strong smell.

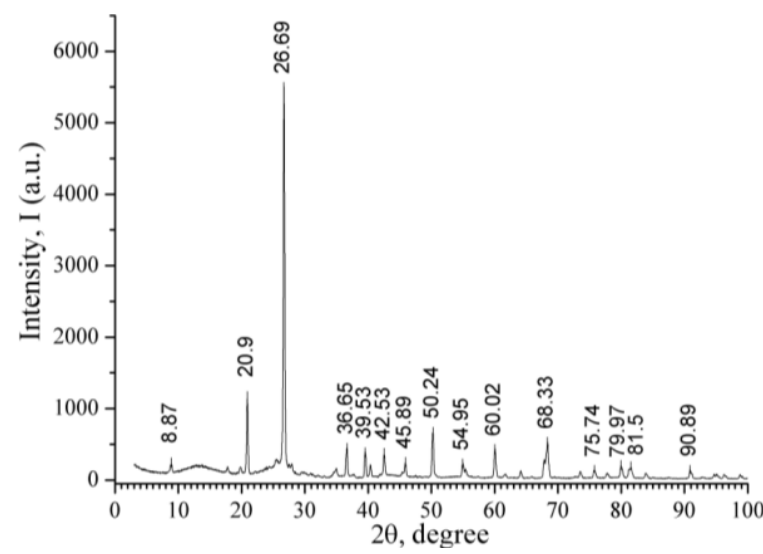

a

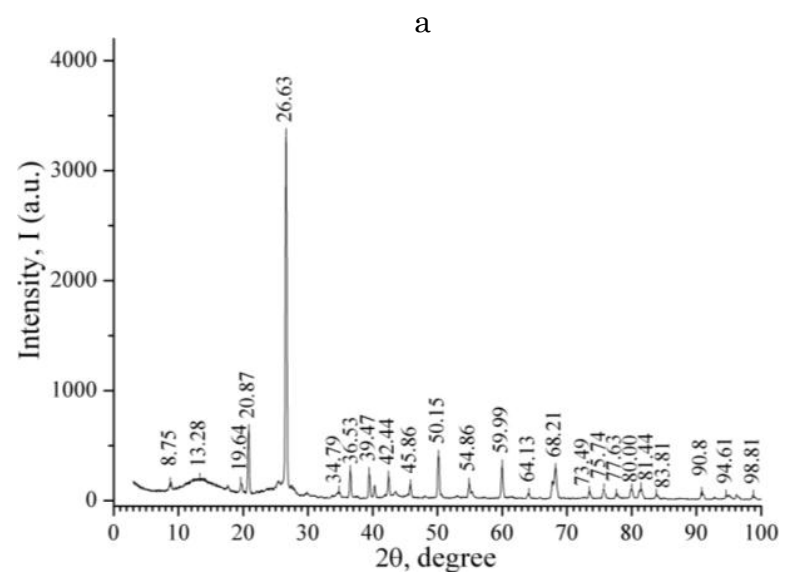

$\mathrm{b}$

Fig. 3 - Diffraction patterns of schungite rock powders: a before heating, $b$ - after heating
Fig. 4 shows the results of experimental studies of specific magnetization temperature dependences. The values of specific magnetization $\sigma$ of the dependences (Fig. 4) prove that the initial substance is a paramagnetic as its specific magnetization is much less than $0.3-0.5 \mathrm{~A} \mathrm{~m}^{2} / \mathrm{kg}$. After heating up to $850 \mathrm{~K}$ the development of the dependences $\sigma=f(T)$ will take the form that is typical of a weak magnetic substance having a small magnetic moment at room temperature. When crushed the reactivity of schungite rock decreases from 1300 to $510{ }^{\circ} \mathrm{C}$. Internal size effect becomes apparent. The formation of new substances increases magnetic properties of schungite powder by seven times [12]. Heat-treated schungite powder with improved protectivity against microwave radiation propagation [13] can be used in construction industry.

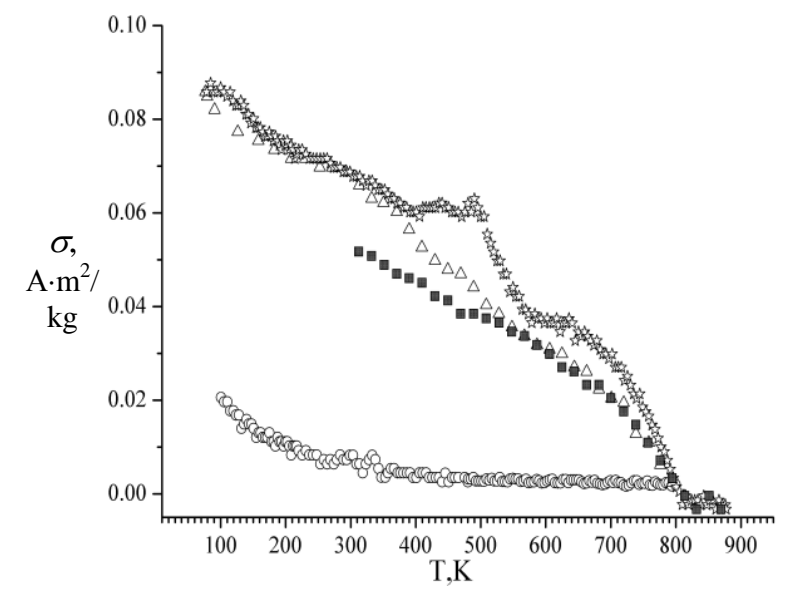

Fig. 4-Changes in the specific magnetization of schungite powders under heating and cooling conditions. $\circ-$ heating, $\Delta-$ cooling,, heating, $\mathbf{- 1}$ - cooling

With their potential size effects mineral powders can be important raw materials for the production of different composite materials with desired properties. The rate of size effects can be controlled by doping the surface of a powder by the milling equipment material by dissolving oxides with either acid or alkali solutions [14], or by hydrolysis of mineral salts [15], or by "dry" chemical reactions with treating powders by means of electro-magnetic radiation or laser [16]. Today the family of well-researched natural mineral formations with potential size effects [17] includes native gold and platinoids (with cluster sizes from 50 to $150 \mathrm{~nm}$ ) from so called non-placer accumulations. Other minerals of the kind are commercial diamonds (ballas or carbonado), rare-earth kularit aggregates, opals and quartz, ocean bottom concretionary formations, leucoxene dioxide aggregates, preserved dump pits of ore mining and processing enterprises, ilmenite and zirconium concentrates.

\section{CONCLUSIONS}

The investigation of iron ore and schungite powders show that their particles are structured as microheterogeneous systems. The powders are characterized by the presence of size effects. In the process of crushing and other production operations iron nanoparticles are transferred from equipment surfaces onto the sur- 
faces of iron ore concentrate microparticles thus increasing specific magnetization of the dry concentrate. Due to its important magnetic properties iron concentrate produced at ore mining and processing enterprises can be used to clean water or land surfaces from oil or oil products by means of magnetic field. Moreover, it can be used to remove radioactive or toxic contaminations.

When schungite rock powder is heated up to $510^{\circ} \mathrm{C}$, internal size effect develops, which is demonstrated in a decrease of the onset temperature of "dry" redox reactions. A structural change in schungite rock powder is accompanied by the increase of its specific magnetization by seven times. Heat-treated schungite rock powder can be used in construction industry as a protection against microwave radiation propagation.

Mineral powders with their potential size effects can be a very important raw material for the production of different composite materials with desired properties.

\title{
Влияние размерных әффектов на свойства перерабатываемой железной руды и шунгитовой породы
}

\author{
Ю.А. Миргород ${ }^{1}$, С.Г. Емельянов ${ }^{1}$, В.М. Федосюк ${ }^{2}$, С.Б. Большанина ${ }^{3}$
}

1 Юго-Западньй государственный университет, ул. 50лет Октября, 94, 305044 Курск, Россия

2 Научно-практический центр НАН Беларуси по материаловедению, Институт фбизики твердого тела и полупроводников НАН Беларуси, ул. П. Бровки, 19, 220072 Минск, Республика Беларусь

${ }_{3}$ Сумский государственный университет, ул. Рилского-Корсакова, 2, 40007 Сумы, Украина

Для исследования структуры и магнитных свойств железной руды и шунгитовой породы были использованы методы сканирующей электронной микроскопии, энергодисперсионной спектроскопии, рентгеновской дифрактометрии и магнитометрии. Результаты показывают наличие внешнего размерного эффекта в железорудном концентрате. Это связано с проникновением наночастиц железа с поверхности оборудования на поверхность порошка, что увеличивает удельную магнитную насыщенность порошка в 1,6 раза по сравнению с чистым магнетитом. В результате внутреннего размерного эффекта в шунгитовом порошке его реакционная способность уменьшается к $800{ }^{\circ} \mathrm{C}$ и после термической обработки порошка его удельная магнитная насыщенность увеличивается в семь раз. С учетом применения размерных әффектов, исследованные порошки и отработанные природные минеральные порошки рекомендуются для использования в производстве композиционных материалов.

Ключевые слова: Размерный әффект, Физические и химические методы, Порошок, Наночастицы, Железная руда, Шунгитовая порода, Структура, Удельная намагниченность.

\section{Вплив розмірних ефектів на властивості залізної руди і шунгітовой породи при їх переробці}

\author{
Ю.О. Миргородㄹ, С.Г. Смельянов ${ }^{1}$, В.М. Федосюк², С.Б. Большаніна ${ }^{3}$
}

1 Південно-Західний державний університет, вул. 50 лет Октября, 94, 305044 Курськ, Росія

2 Науково-практичний иентр НАН Білорусі з матеріалознавства, Інститут фбізики твердого тіла $і$ напівпровідників НАН Білорусі, вул. П. Бровки, 19, 220072 Мінськ, Республіка Білорусь

${ }^{3}$ Сулский державний університет, вул. Римського-Корсакова, 2, 40007 Суми, Украӥна

\begin{abstract}
Для дослідження структури і магнітних властивостей залізної руди і шунгітової породи були використані методи скануючої мікроскопії, електронної мікроскопії, енергодисперсійної спектроскопії, рентгеновскої дифрактометрії і магнітометрії. Результати показують наявність зовнішнього розмірного ефекту в залізорудному концентраті. Це пов'язано з проникненням наночастинок заліза 3 поверхні обладнання на поверхню порошку, що збільшуе питому магнітну насиченість порошку в 1,6 рази порівняно з чистим магнетитом. В результаті внутрішнього розмірного ефекту в шунгітовому порошку його реакційна здатність зменшуеться до $800^{\circ} \mathrm{C}$ і після термічної обробки порошку його питома магнітна насиченість збільшуеться у сім разів. 3 урахуванням розмірних ефектів досліджені порошки і відпрацьовані природні мінеральні порошки рекомендуються для використання у виробництві композиційних матеріалів.
\end{abstract}

Ключові слова: Розмірний ефект, Фізичні та хімічні методи, Порошок, Залізна руда, Наночастинки, Шунгітова порода, Структура, Питома намагніченість 


\section{REFERENCES}

1. G.B. Sergeev, K.J. Klabunde, Nanochemistry. 2nd Edition. (Elsevier: 2013).

2. N.F. Uvarov, V.V. Boldyrev, Russ. Chem. Rev. 70, 265 (2001).

3. M.D. Engel, P.D. Middlebrook, G.J. Jameson, Mineral. Eng. 10 (1), 55 (1997).

4. F. Cheng, Q. Cao, Y. Guan, H. Cheng, X. Wang, J.D. Miller, Int. J. Mineral Process. 122, 36 (2013).

5. M.L. Rivas-Sanchez, L.M. Alva-Valdivia, J. ArenasAlatorre, J. Urrutia-Fucugauch, M. Perrin, A. Goguitchaichvil, M. Ruiz-Sandoval, M.A. Ramos Molina, Earth Planets Space 61, 151 (2009).

6. V.V. Kovalevsky, Diss. Doctor of Geological-mineral. Science (Petrozavodsk: 2007).

7. Yu.A. Mirgorod, N.A. Borsch, V.M. Fedosyuk, G.Y. Yurkov, Rus. J. Appl. Chem. 82, 1357 (2009).

8. Handbook of Magnetic Materials (Ed. K.H. Bushow) (Elsiver: 2006)

9. S.S. Aplesnin, G.I. Barinov, Solid State Phys. 49, 1858 (2007).

10. J.A. Mirgorod, S.G. Emel'janov, N.A. Borsh,
V.M. Fedosjuk, S.S. Khotynjuk. Pat. RU 2462303, Russia. Publ. 27.09.2012.

11. S. Emelyanov, A. Kuzmenko, V. Rodionov, M. Dobromyslov. J. Nano- Electron. Phys. 5 No 4, 04023 (2013).

12. J.A. Mirgorod, S.G. Emel'janov, V.M. Fedosjuk, Pat. RU 2485729, Russia, publ. 20.06.2013.

13. N.E. Kazantseva, N.G. Ryvkina, N.A. Chmutin. J. Commun. Technol. Electron. 48 (2), 196 (2003).

14. P.K. Abratis, R.A.D. Patrick, G.H. Kelsall, D.J. Vaughan, Mineralogical Magazine 68 (2), 343 (2004).

15. Y.M. Nasser, M.H.H. Mahmoud, Z.K. Heiba, Hydrometallurgy. 139, 88 (2013).

16. A.P. Kuz'menko, I.Yu. Rasskazov, N.A. Leonenko, G.G. Kapustina, I.V. Silyutin, J. Li, N.A. Kuz'menko, I.V. Khrapov, J. Mining Sci. 47 (6), 850 (2011).

17. A.A. Kotov, M.B. Tarbaev, V.A. Petrovski, Micro-and nanomineralizatsiya in placer and ore-loose objects in Russia. Geomaterials for high technology (Syktyvkar: Geoprint: 2010). 